\title{
Lead Behavior in Soil Treated with Contaminated Sewage Sludge and Cultivated with Maize
}

\author{
Marcilene Ferrari Barriquelo, Marinês Aparecida Juliatti, Margarete Soares da Silva and \\ Ervim Lenzi* \\ Departamento de Química, Universidade Estadual de Maringá - UEM; Av. Colombo, 5790; 87020-900; Maringá - \\ PR - Brazil
}

\begin{abstract}
Lead $(\mathrm{Pb})$ behavior was studied in soil treated twice with sewage sludge contaminated with lead at interval of 18 months. Soil samples received five different treatments: three with lead [0 (reference); 2,500; 5,000 $\left.\mu \mathrm{g} \mathrm{g}^{-1}\right]$ and two with a mixture of lead and cadmium (interferer) $\left(2,500+2,500\right.$ and $5,000+5,000 \mu \mathrm{g}^{-1}$, respectively). Vases containing treated soil were cultivated with maize in a greenhouse for 75 days. Pb was extracted using nitric perchloric digestion and analyzed by atomic absorption spectroscopy. The soil, containing sewage sludge contaminated by lead presented a higher concentration of $P b$. The metal concentration remained constant in all treatments at 20-60 cm depth. No absorption of $\mathrm{Pb}$ by the plants was detected.
\end{abstract}

Key words: Sewage sludge, heavy metal, lead, environmental pollution

\section{INTRODUCTION}

The application of sewage sludge (biosolid) in agriculture has become a common practice. However, the presence of heavy metals in sewage sludge may be a factor limiting its use. These heavy metals generally come from effluents disposal together with domestic sewage. Successive agricultural applications may result in accumulation of these elements in the environment and in the food chain: sewage $\Rightarrow$ soil $\Rightarrow$ plant $\Rightarrow$ animal $\Rightarrow$ man (Kabata - Pendias and Pendias, 1992).

According to Berti and Jacobs (1996), sewage sludge may be used in agriculture for increasing product yield. However, sometimes it can present high metal concentration $(\mathrm{Cd}, \mathrm{Cu}, \mathrm{Ni}, \mathrm{Pb}$ and $\mathrm{Zn})$ that can cause serious problems in plants and its consumers. High concentrations of metals can change plant biological processes, such as: photosynthesis, respiration, enzyme activity and growth, which may result in a lower production (Malavolta, 1994). Nevertheless, some studies have shown a high yield after sludge application, because its content of macro and micronutrients.

Berton et al. (1989) detected a meaningful increase in the production of dry matter and $\mathrm{N}, \mathrm{P}$, $\mathrm{Ca}, \mathrm{Mg}$ and $\mathrm{Zn}$ absorption by maize in 5 soils of São Paulo State (Brazil) using higher sludge doses (40 and $80 \mathrm{t} \mathrm{ha}^{-1}$ of dry matter). Silva (1995) used sludge doses of 0,20 and $40 \mathrm{t} \mathrm{ha}^{-1}$ complemented by NPK and detected a linear increase in sugar cane production during the first year of crop. No

\footnotetext{
* Author for correspondence
} 
heavy metal was found in the sugar syrup produced in this experiment. Da Ros et al. (1993) using $0,20,40,80$ and $160 \mathrm{tha}^{-1}$ doses, wet base, detected a meaningful increase in dry matter production. This effect was observed in two different ways: immediate increase on millet production and residual effect on production of oat associated with vetch. There was a reasonable increase in absorption of $\mathrm{N}, \mathrm{P}_{2} \mathrm{O}_{5}$ and $\mathrm{K}_{2} \mathrm{O}$ by millet when sewage sludge was used.

According to the information as above, it can be observed that there is no general agreement concerning the exact dose of sewage sludge for each crop. This may be due to great fluctuations in its composition, the difficulty in foreseeing the behavior of metals in different types of soil and distinct nutritional requirements of each crop.

The main anthropogenic sources of metals in the environment are: fertilizers, pesticides, irrigation water, biomass burning, coal and oil combustion, pollutants from vehicles, incineration of urban and industrial trash and, specially, residues from tanning industry, mining activities, foundries and industrial refineries (Tavares and Carvalho, 1992; Adriano, 1986).

Many researchers have been studying the effect of heavy metals following their accumulation in the environment. They generally work with the soil layer containing the highest fertility index $0-20 \mathrm{~cm}$ deep layer, which is widely used for agricultural purposes. Lead accumulates at the first centimetres of soil surface and its concentration decreases with the depth. In some cases, it may be found at 30-45 cm depth (Malavolta, 1994). Chang et al. (1984) were found that $90 \%$ of metals of a soil treated with sewage sludge during six years in the first $15 \mathrm{~cm}$. Alloway (1990) had stated that lead accumulates in soils and sediments due to its low solubility and fact that it undergoes no microbial degradation. Brady (1989) mentioned that $\mathrm{Pb}$ has a very low solubility in non-acid soils.

Heavy metals react with diffusing binders, macromolecules and membrane binders. This results in accumulation in the food chain and disturbances in the metabolic processes of living organisms. Bioaccumulation transforms normal concentrations into toxic concentrations in different biotic species and man (Tavares and Carvalho, 1992). Thus, it is necessary to be alert and aware of the use of organic fertilizers produced from sewage sludge. These products always contain a somewhat higher concentration of heavy metals. With this context, the present research work evaluated the behavior of the $\mathrm{Pb}$ in oxisol (Dark Red Latisol) treated with sewage sludge contaminated by lead in which maize was cultivated after 18 months from the first treatment.

\section{MATERIALS AND METHODS}

Experiment in PVC (polyvinylchloride) vases (diameter $=10 \mathrm{~cm}$ and height $=80 \mathrm{~cm}$ ) was carried out in a green house. Along the vase, beginning from $20 \mathrm{~cm}$ in depth, gauge tubes containing the same vase soil were placed vertically at $10 \mathrm{~cm}$ intervals up to $60 \mathrm{~cm}$ (Fig. 1 Part A). The internal part of the gauge tubes containing samples for analysis was perforated to allow water (soil solution), together with the contaminant, to flow throughout the soil in gauge. Concentration and, indirectly, percolation and possible diffusion could be determined (Fig. 1 Part B).

Dark Red Latisol samples were collected vertically at $20 \mathrm{~cm}$ intervals up to a depth of $80 \mathrm{~cm}$ from the region of Maringá (Paraná, Brazil). Table 1 shows its chemical and physical characteristics.

The first layer of each vase $(0-20 \mathrm{~cm})$ was manured with $6 \mathrm{t} \mathrm{ha}^{-1}$ dose of sewage sludge contaminated by $\mathrm{Pb}^{2+}$ in concentrations: $0 ; 2,500$ and $5,000 \mu \mathrm{g} \mathrm{g}^{-1}$ (in the form of $\mathrm{PbCl}_{2}$ ) and with a mixture of lead $\left(\mathrm{Pb}^{2+}\right)$ and cadmium $\left(\mathrm{Cd}^{2+}\right)$ (as interferer in the lead behavior) in $\mu \mathrm{g} \mathrm{g}^{-1}$ concentrations of 2,500 and 5,000, respectively, after 18 months from the first identical treatment. The $\mathrm{pH}$ was determined by potentiometer in the soil:water ratio of 1:2.5. Liming need was determined by SMP method. A 3:1 mixture of calcium carbonate and magnesium carbonate was used for liming (dry base) and the soil sample was incubated for 15 days to raise $\mathrm{pH}$ to 6.5 .

Sewage sludge was collected at SANEPAR, Maringá, Paraná, Brazil. After homogenization and drying, three portions were taken, digested with a nitric perchloric solution and $\mathrm{K}, \mathrm{Ca}, \mathrm{Mg}, \mathrm{S}, \mathrm{Cu}, \mathrm{Zn}$, $\mathrm{Fe}, \mathrm{Mn}, \mathrm{Pb}$ and $\mathrm{Cd}$ concentrations were determined by atomic absorption spectrometry. 
Concentrations of $\mathrm{N}$ was determined with Kjeldahl method, $\mathrm{P}$ was determined by UV-Vis spectrophotometric method of the phosphomolibdic complex, and $\mathrm{C}$ was determined by Walkley and

Table 1 - Chemical and physical characteristics of soil.

\begin{tabular}{|c|c|c|c|c|c|c|c|c|c|c|c|c|}
\hline Soils & $\mathrm{pH}\left(\mathrm{H}_{2} \mathrm{O}\right)$ & $\mathbf{A l}^{3+}$ & $\mathrm{H}^{+}+\mathrm{Al}^{3+}$ & $\mathrm{Ca}^{2+}$ & $\mathrm{Mg}^{2+}$ & $\mathbf{K}^{+}$ & $\mathrm{Fe}$ & $\mathbf{C u}$ & Mn & clay & silt & sand \\
\hline & & $\longleftarrow$ & $-\mathrm{cm}$ & $\mathrm{dm}^{-3}$ & 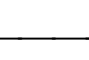 & $\rightarrow$ & $\longleftarrow$ & $\mathrm{mg} \mathrm{dm} \mathrm{m}^{-3}$ & $\longrightarrow$ & $\longleftarrow$ & $\mathrm{g} \mathrm{kg}^{-1}$ & $\longrightarrow$ \\
\hline $\mathrm{LEd}^{\dagger}$ & 5.3 & 0.00 & 0.76 & 0.96 & 0.35 & 0.03 & 114.7 & 2.97 & 75.7 & 320 & 20 & 660 \\
\hline
\end{tabular}

$\dagger$ LEd - Dark Red Latisol.

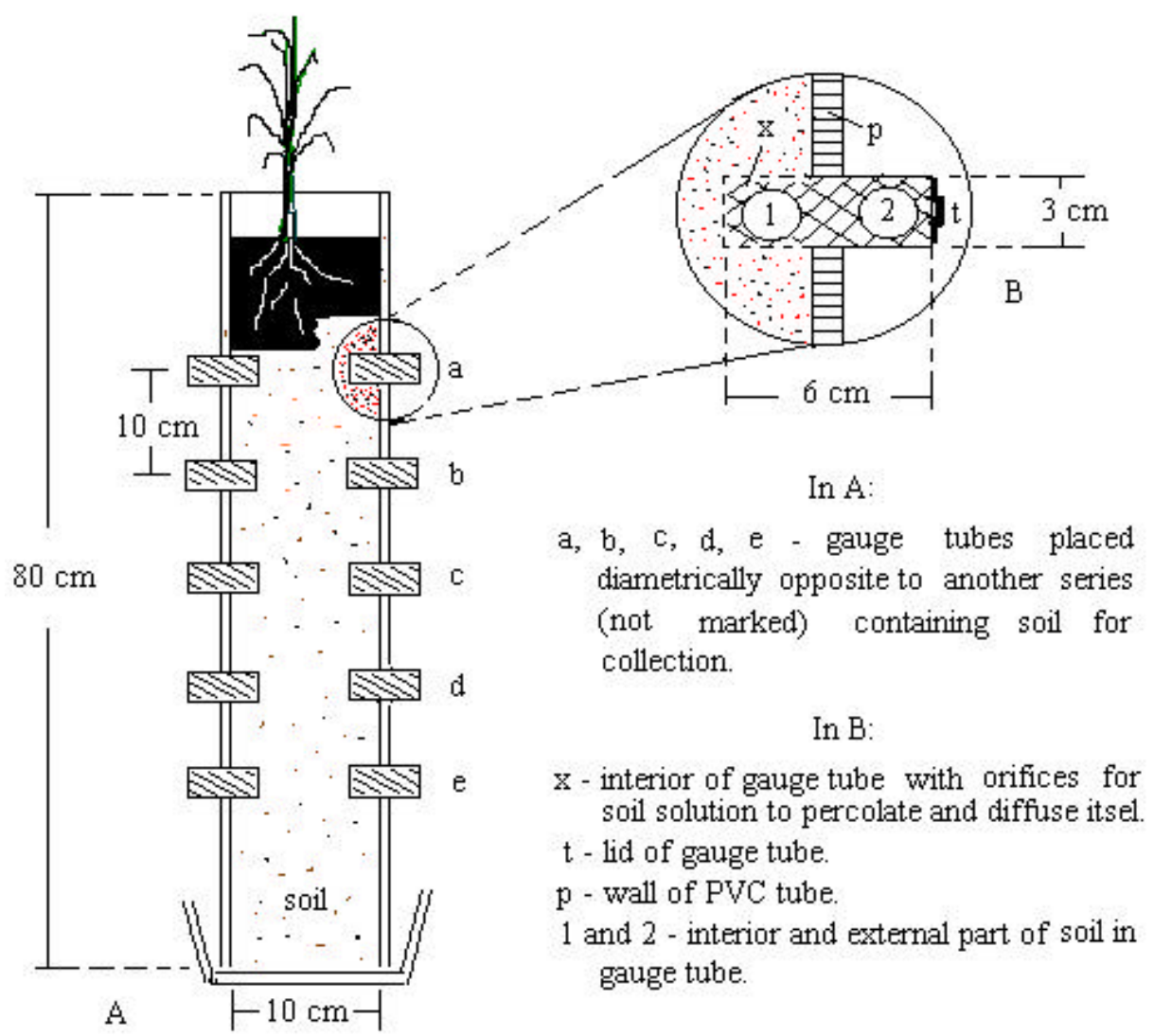

Figure 1 - Front cross section of PVC (polyvinylchloride) tube (diameter $=10 \mathrm{~cm}$ and height $=80 \mathrm{~cm}$ ) with soil and gauge tubes (part A) and details of cross section of gauge tube (Part B).

After the incubation period, five maize seeds were sown in each vase. Seven days after germination, plants were pared and three plants were left per vase. The shoots were assisted daily. Random shiftings were made in the vases position. In order to allow the percolation of contaminants, the plants were watered every seven days with twice as
Black method (Embrapa, 1999; Pavan et al., 1992). Table 2 shows the results of the sewage sludge analysis. 


\begin{tabular}{|c|c|c|c|c|c|c|c|c|c|c|c|c|c|}
\hline Material & $\mathrm{N}$ & $\mathrm{P}$ & $\mathrm{K}$ & $\mathrm{Ca}$ & $\mathrm{Mg}$ & $\mathrm{S}$ & $\mathrm{C}$ & $\mathrm{Cu}$ & $\mathrm{Zn}$ & $\mathrm{Fe}$ & $\mathrm{Mn}$ & $\mathrm{Pb}$ & $\mathrm{Cd}$ \\
\hline & & & & 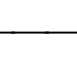 & & & & $\longrightarrow$ & $\longleftarrow$ & & ppm & 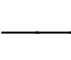 & $\longrightarrow$ \\
\hline Sludge ${ }^{\dagger}$ & 2.92 & 0.82 & 0.18 & 3.08 & 1.02 & 0.32 & 24.3 & 146 & 1.327 & 6128 & 262 & 122 & 3.50 \\
\hline
\end{tabular}

$\dagger$ - Sewage sludge.

Seventy-five days after the emergence of the maize plant, the upper part of the plant was cut close to the ground and air-dried separately according to the vase distribution. Then, it was placed in an incubator at $80^{\circ} \mathrm{C}$ for 48 hours (Scott et al., 1971), weighed, ground and digested with a mixture of nitric and perchloric acid (Malavolta et al., 1997). $\mathrm{Pb}$ concentration was determined by atomic absorption spectrophotometer.

Soil was sampled from the $0-20 \mathrm{~cm}$ layer and from the gauge tubes. The samples from each gauge tube were divided into internal (i) and external (e) samples. They were ground in a porcelain mortar, sieved and digested with a mixture of nitric and perchloric acid (Horwitz, 1980). $\mathrm{Pb}$ concentration was obtained by atomic absorption spectroscopy. The data obtained were evaluated by variance analysis and Tukey test at 5\%, using SANEST software.

\section{RESULTS AND DISCUSSION}

\section{Lead in the plant}

Table 3 shows the results of $\mathrm{Pb}$ concentrations in the aerial part of the plant. No absorption of $\mathrm{Pb}$ by the maize plant was detected. Regarding the production of dry matter (g/vase), there was no meaningful difference between all the treatments, at 5\% level. Others ions present in solution (ex: $\mathrm{Ca}^{2+}$ ) probably competed with the absorption of $\mathrm{Pb}^{2+}$ by plants and its absorption was very low, as observed by Berton et al. (1992). According to Adriano (1986) available forms of $\mathrm{Pb}$ (soluble + exchangeable) resulting from sewage sludge application correspond to $1.6 \%-8.0 \%$ of total accumulation. Uptake studies of forage crops indicated that only a very small fraction $(0.3 \%$ to $0.5 \%$ ) of added $\mathrm{Pb}$ was utilized by plants.

Table $3-\mathrm{Pb}$ concentration and production of dry matter in the aerial part of plants $\mathrm{s}^{\dagger}$.

\begin{tabular}{lcc}
\hline \multicolumn{1}{c}{ Treatment } & $\mathrm{Pb}\left(\mu \mathrm{gg}^{-1}\right)$ & $\mathrm{g} / \mathrm{vase}^{ \pm} \mathrm{s}^{\ddagger}$ \\
\hline Reference & $\mathrm{ND}$ & $20.78 \pm 2.95 \mathbf{a}^{\S}$ \\
$\mathrm{Pb}(2,500)$ & $\mathrm{ND}$ & $20.17 \pm 0.75 \mathbf{a}$ \\
$\mathrm{Pb}(5,000)$ & $\mathrm{ND}$ & $19.36 \pm 0.84 \mathbf{a}$ \\
$\mathrm{Cd}(2,500)+\mathrm{Pb}(2,500)$ & $\mathrm{ND}$ & $18.38 \pm 1.82 \mathbf{a}$ \\
$\mathrm{Cd}(5,000)+\mathrm{Pb}(5,000)$ & $\mathrm{ND}$ & $17.83 \pm 1.39 \mathbf{a}$ \\
\hline
\end{tabular}

$\dagger$ - Results are averages of triplicate analyses; ND - Not detected; $\$$ - standard deviation (s); $\$$-values followed by different letters $(\mathbf{a}, \mathbf{b}, \mathbf{c} \ldots)$ presents significant difference by Tukey test at $5 \%$.

Absorption and translocation of metals in plants occur differently for each metal and culture (Wallace and Romney in Adriano 1986): - B, Mn, $\mathrm{Ni}$ and $\mathrm{Zn}$ in plants are usually distributed more or less uniformly between roots and aerial part; - Co, $\mathrm{Cu}, \mathrm{Mo}$ and $\mathrm{Cd}$ generally present higher rates in roots and moderate to great quantities in the aerial part; - $\mathrm{Cr}, \mathrm{Pb}, \mathrm{As}, \mathrm{Sn}, \mathrm{Ti}$ and $\mathrm{V}$ concentrate themselves mainly in the roots and slightly in the aerial part. However, distribution standards may vary according to species and concentration of the element in the layer.

Silva (1995) observed no effect in metal concentration in the tissue and in the export of $\mathrm{Cd}$, $\mathrm{Cr}, \mathrm{N}, \mathrm{Pb}$ and $\mathrm{Se}$ in the sugar cane stalk + leaves with the addition of sewage sludge. Berti and Jacobs (1996) stated that $\mathrm{Pb}$ was not detected in the plant in all crops evaluated. The sorption (adsorption and absorption) of $\mathrm{Pb}$ by the maize plant could be also attributed to its probable concentration in the roots (Malavolta, 1994) and low bioavailability (Zufiaurre et al., 1998; Berti and Jacobs, 1996; McBride, 1995; Hooda and Alloway, 1994).

\section{Lead in the soil}

Sewage sludge may be an important source of heavy metals in agricultural soils (Hooda and Alloway, 1994). In this experiment, the second application of sewage sludge contaminated with 
lead after an 18 months interval from first application showed an accumulation of metal in the soil (Figs. 2 and 3).

According with the results of lead concentration in soil (Table 4), after two applications, a higher concentration of this metal was detected in the 0$20 \mathrm{~cm}$ layer. This was the layer in which the sewage sludge was incorporated. In $20-60 \mathrm{~cm}$ depth layer the concentration of $\mathrm{Pb}$ remained unchanged and there was no significant difference, at 5\% level, between concentrations of $\mathrm{Pb}$ in the internal and external sections of the gauge tube. Therefore, it could be stated that there was no percolation or diffusion of $\mathrm{Pb}$ throughout the soil column. These results agreed with those obtained by other researchers (Silva, 1997; Chang et al., 1984). No $\mathrm{Pb}$ was found $\mathrm{Pb}$ in the collected percolation water in the simulation of the highest rainfall season of Maringá region.

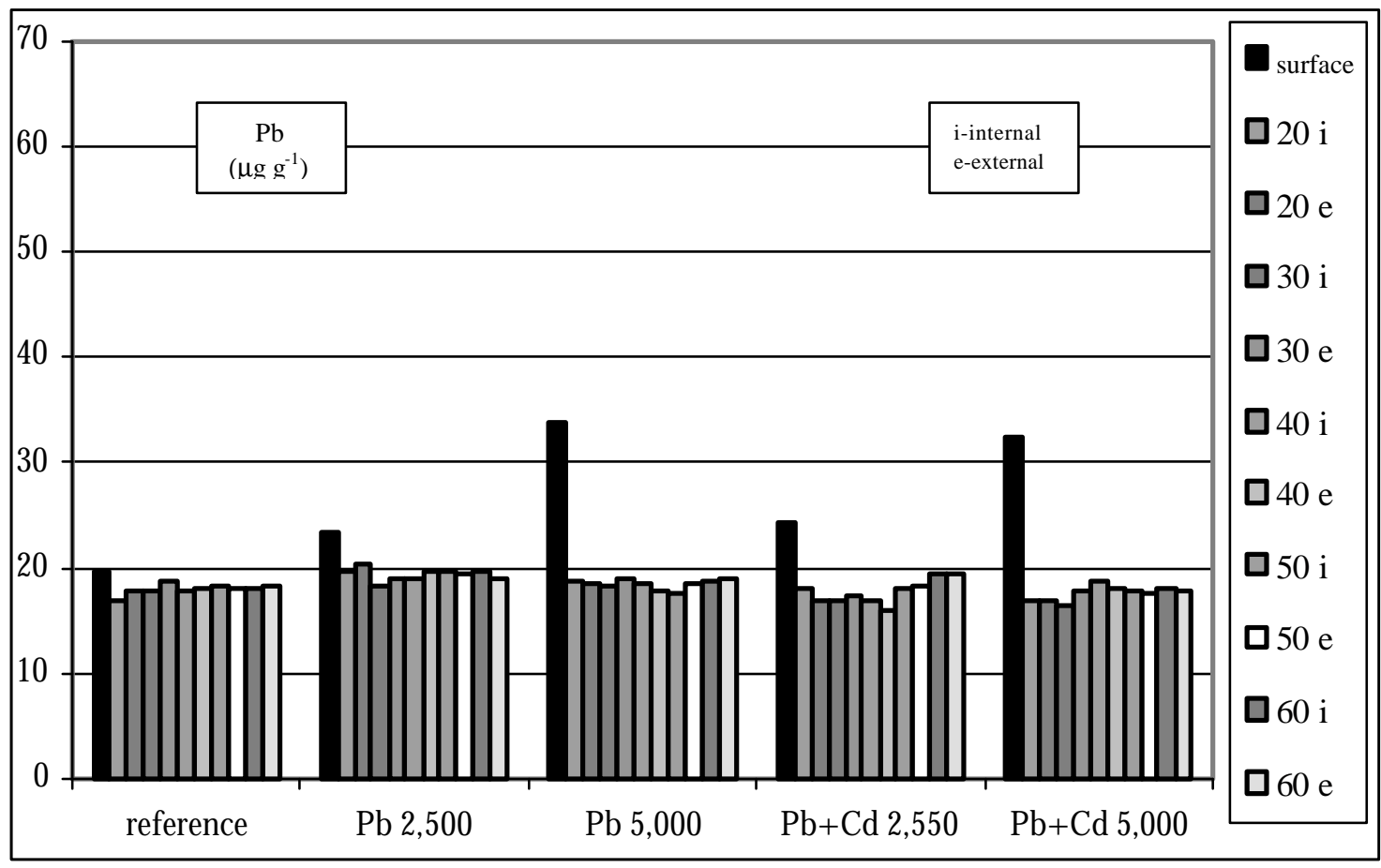

Figure 2 - Concentration of $\mathrm{Pb}$ in soil treated with sewage sludge - first application (Silva, 1997).

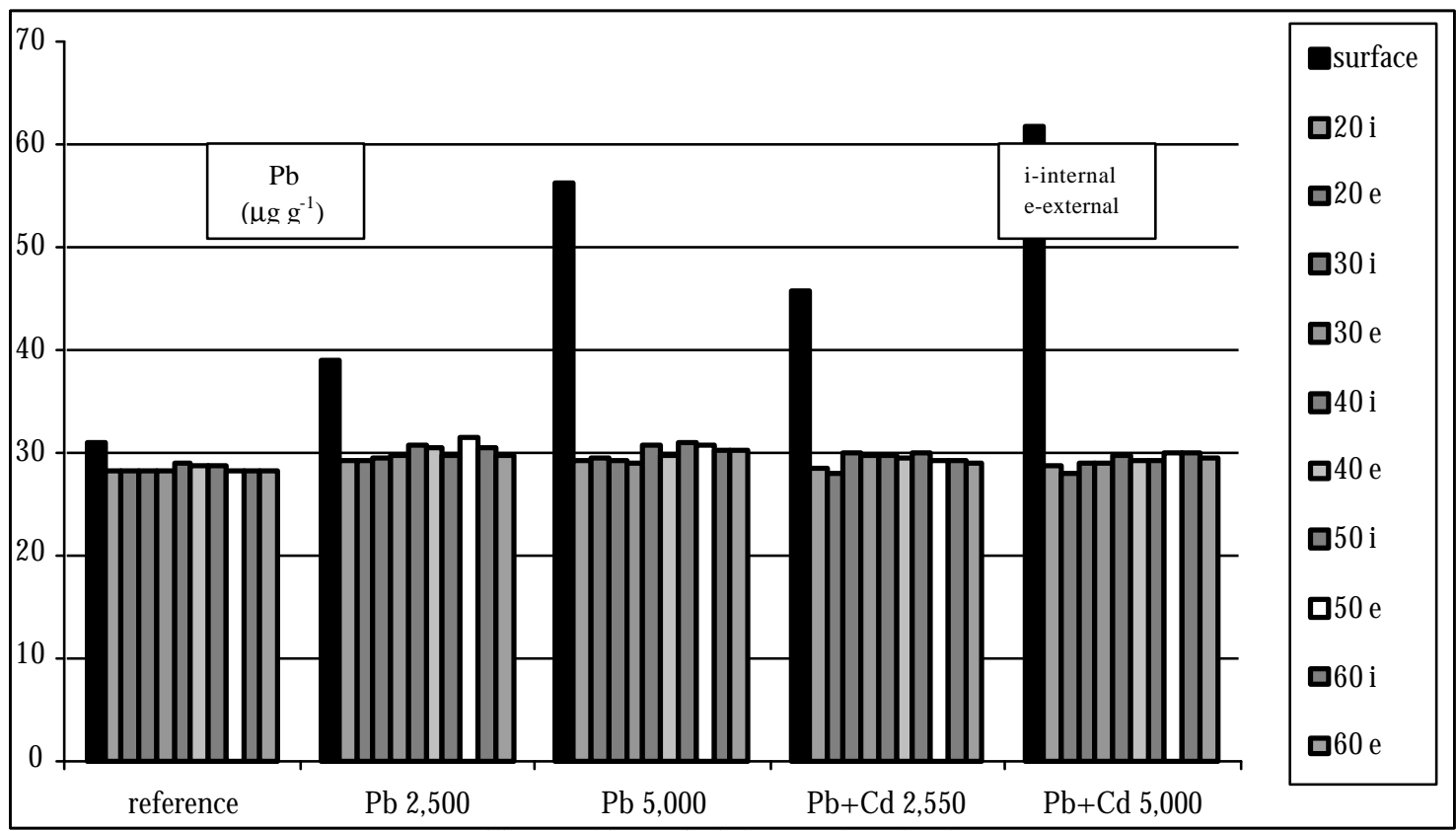

Brazilian Archives of Biology and Technology 
Figure 3 - Concentration of $\mathrm{Pb}$ in soil treated with sewage sludge - second application.

No interaction was observed between $\mathrm{Cd}$ and $\mathrm{Pb}$ behavior in the treated soils. The typical behavior of $\mathrm{Pb}$ in contaminated soils included high retention (Amaral Sobrinho et al., 1997), low mobility (Matos et al., 1996; Sheppard and Thibault, 1992; Chang et al., 1984) and low bioavailability (Kádár, 1994; Alloway, 1990) and has been attributed to its high affinity to the fractions: Fe-oxide, Mn-oxide and residual (Zafiaurre et al., 1998; Amaral Sobrinho et al., 1997; Gomes et al., 1997).

\section{CONCLUSIONS}

Higher concentrations of $\mathrm{Pb}$ were observed only in the $0-20 \mathrm{~cm}$ superficial layer. Concentrations remained unchanged at the 20-60 $\mathrm{cm}$ depth layer. No interference of $\mathrm{Cd}$ in the behavior of $\mathrm{Pb}$ was detected. There was no absorption of lead by maize plants after being cultivated in soil treated twice with sewage sludge contaminated by this metal.

Table 4 - Concentrations of $\mathrm{Pb}$ in soil for different treatments

\begin{tabular}{|c|c|c|c|c|c|c|}
\hline \multirow{2}{*}{\multicolumn{2}{|c|}{$\begin{array}{l}\text { Depth } \\
\text { (cm) }\end{array}$}} & \multicolumn{5}{|c|}{ Treatments } \\
\hline & & $\begin{array}{c}\text { Reference } \\
\left(\mu \mathrm{g} \mathrm{g}^{-1}\right)\end{array}$ & $\begin{array}{c}\text { Pb 2,500 } \\
\left(\mu g^{-1}\right)\end{array}$ & $\begin{array}{c}\text { Pb 5,000 } \\
\left(\mu g^{-1}\right)\end{array}$ & $\begin{array}{c}\text { Pb 2,500 + Cd 2,500 } \\
\left(\mu \mathrm{g} \mathrm{g}^{-1}\right)\end{array}$ & $\begin{array}{c}\text { Pb 5,000 + Cd 5,000 } \\
\left(\mu \mathrm{g} \mathrm{g}^{-1}\right)\end{array}$ \\
\hline \multicolumn{2}{|c|}{ Surface } & $31.01 \mathbf{a}^{\dagger}$ & $38.96 \mathbf{a}$ & $56.32 \mathbf{a}$ & $45.62 \mathbf{a}$ & $61.90 \mathbf{a}$ \\
\hline \multirow[t]{2}{*}{20} & $\mathbf{i}$ & $28.25 \mathbf{b}$ & 29.19 b & $29.30 \mathbf{b}$ & $28.58 \mathbf{b}$ & $28.75 \mathbf{b}$ \\
\hline & $\mathbf{e}$ & $28.16 \mathbf{b}$ & $29.27 \mathbf{b}$ & $29.58 \mathbf{b}$ & $28.00 \mathbf{b}$ & $28.08 \mathbf{b}$ \\
\hline \multirow[t]{2}{*}{30} & $\mathbf{i}$ & $28.33 \mathbf{b}$ & $29.33 \mathbf{b}$ & $29.25 \mathbf{b}$ & $29.91 \mathbf{b}$ & $28.95 \mathrm{~b}$ \\
\hline & $\mathbf{e}$ & $28.20 \mathbf{b}$ & $29.69 \mathbf{b}$ & $28.94 \mathbf{b}$ & $29.64 \mathbf{b}$ & $28.94 \mathbf{b}$ \\
\hline \multirow[t]{2}{*}{40} & $\mathbf{i}$ & $28.92 \mathbf{b}$ & $30.58 \mathbf{b}$ & $30.80 \mathbf{b}$ & $29.74 \mathbf{b}$ & $29.77 \mathbf{b}$ \\
\hline & $\mathbf{e}$ & $28.75 \mathbf{b}$ & $30.47 \mathbf{b}$ & $29.76 \mathbf{b}$ & $29.42 \mathbf{b}$ & $29.24 \mathbf{b}$ \\
\hline \multirow[t]{2}{*}{50} & $\mathbf{i}$ & $28.75 \mathbf{b}$ & $29.83 \mathbf{b}$ & $30.91 \mathbf{b}$ & $29.88 \mathbf{b}$ & $29.30 \mathbf{b}$ \\
\hline & $\mathbf{e}$ & $28.25 \mathbf{b}$ & $31.47 \mathbf{b}$ & $30.72 \mathbf{b}$ & $29.24 \mathbf{b}$ & $30.13 \mathbf{b}$ \\
\hline \multirow[t]{2}{*}{60} & i & $28.25 \mathbf{b}$ & $30.52 \mathbf{b}$ & $30.16 \mathbf{b}$ & $29.19 \mathbf{b}$ & $30.06 \mathbf{b}$ \\
\hline & $\mathbf{e}$ & $28.33 \mathbf{b}$ & $29.83 \mathbf{b}$ & $30.30 \mathbf{b}$ & $29.08 \mathbf{b}$ & $29.38 \mathbf{b}$ \\
\hline
\end{tabular}

i - internal section of gauge tube; $\mathbf{e}$ - external section of gauge tube; $t$ - values of the same column followed by different letters $(\mathbf{a}, \mathbf{b}, \mathbf{c} \ldots)$ presents significant difference at $5 \%$ level.

\section{RESUMO}

$\mathrm{O}$ comportamento do $\mathrm{Pb}$ foi estudado num Latossolo Vermelho Escuro tratado com lodo de esgoto (biossólido) contaminado, 18 meses após o tratamento do mesmo. As amostras de solo coletadas num perfil de 0 a $80 \mathrm{~cm}$ de profundidade foram dispostas da mesma forma em tubos de PVC ( $80 \mathrm{~cm}$ de altura e $10 \mathrm{~cm}$ de diâmetro) em triplicata, os quais tinham lateral e diametralmente opostos, a cada $10 \mathrm{~cm}$ de profundidade a partir dos $20 \mathrm{~cm}$ da superfície, tubos sonda contendo o mesmo solo do interior do tubo de PVC. As frações de solo de 0 a $20 \mathrm{~cm}$ de cada tubo, receberam 5 tratamentos: três concentrações de chumbo: 0,0 (referência); 2.500; $5.000 \mu \mathrm{g} \mathrm{g} \mathrm{g}^{-1} \mathrm{e}$ duas com a mistura de chumbo e cádmio (como interferente) nas seguintes proporções: 2.500 :
2.500 e $5.000: 5.000 \mu \mathrm{g} \mathrm{g}^{-1}$, respectivamente. Nos tubos com o solo contaminado, em casa de vegetação, foi cultivado o milho como planta teste, durante 75 dias. Após, as plantas, os solos tratados (0 a $20 \mathrm{~cm})$ e os solos dos tubos sonda foram coletados, preparados e digeridos com ácido nítrico e perclórico. As concentrações de $\mathrm{Pb}$ foram obtidas pelo método da espectrometria de absorção atômica. As amostras de solo da camada de 0-20 $\mathrm{cm}$ foram as que apresentaram as maiores quantidades de chumbo, proporcionais à quantidade adicionada. A concentração de $\mathrm{Pb}$ permaneceu constante na profundidade de 20 a $60 \mathrm{~cm}$, em todos os tratamentos. Não foi detectada a absorção de $\mathrm{Pb}$ pelas plantas.

\section{ACKNOWLEDGMENTS}


We would like to thank the Chemistry Department of the State University of Maringá and CAPES for the support received.

\section{REFERENCES}

Adriano, D. C. (1986), Trace Elements in the Terrestrial Environment. New York : Springer-Verlag.

Alloway, B. J. (Ed.) (1990), Heavy Metals in Soils. New York : John Wiley and Sons.

Amaral Sobrinho, N. M. B.; Velloso, A. C. X. and Oliveira, C. (1997), Solubilidade de Metais Pesados em Solo Tratado com Resíduo Siderúrgico. R. Bras. Ci. Solo, 21, 9-16.

Berti, W. R. and Jacobs, L. W. (1996), Chemistry and Phytotoxicity of Soil Trace Elements from Repeated Sewage Sludge Applications. J. Environ. Qual., 25, 10251032.

Berton, R. S.; Camargo, O. A. and Valadares, J. M. A. S. (1989), Absorção de Nutrientes pelo Milho em Resposta à Adição de Lodo de Esgoto a Cinco Solos Paulistas. $R$. Bras. Ci. Solo, 13, 187-192.

Berton, R. S.; Camargo, O. A. and Valadares, J. M. A. S. (1992), Fertilizantes e Poluição. In: Reunião Brasileira de Fertilidade do Solo e Nutrição de Plantas. Piracicaba. Anais ... Campinas. Fundação Cargill. pp. 299-313.

Brady, N. C. (1989), Natureza e Propriedades dos Solos. 7. ed. Rio de Janeiro : Livraria Freitas Bastos.

Chang, A. C.; Warneke, J. E.; Page, A. L. and Lund, L. J. (1984), Accumulation of Heavy Metals in Sewage Sludge Treated Soils. J. Environ. Qual., 13 : (1), 87-90.

Da Ros, C. O.; Aita, C.; Ceretta, C. A. and Fries, M. R. (1993), Lodo de Esgoto: Efeito Imediato no Milheto e Residual na Associação Aveia-ervilhaca. R. Bras. Ci. Solo, 17, 257-261.

Gomes, P. C.; Fontes, M. P. F.; Costa, L. M. and Mendonça, E. S. (1997), Extração Fracionada de Metais Pesados em Latossolo Vermelho-Amarelo. R. Bras. Ci. Solo, 21, 543551.

Hooda, P. S. and Alloway, B. J. (1994), Changes in Operational Fractions of Trace Metals in Two Soils During Two-Years of Reaction Time Following Sewage Sludge Treatment. Intern. J. Environ. Anal. Chem., 57, 289311.

Horwitz, W. (Ed.) (1980), Official Methods of Analysis of the Association of Official Analytical Chemists $A O A C$. 13. ed. Washington : The Association of Official Analytical Chemists.

Kabata-Pendias, A. and Pendias, H. (1992), Trace Elements in Soils and Plants. 3. ed. Boca Raton : CRC.

Kádár, I. (1994), Effect of Heavy Metal Load on Soil and Crop. Acta Agron. Hung., 43, 3-9.

Malavolta, E. (1994), Fertilizantes e seu Impacto Ambiental: Micronutrientes e Metais Pesados, Mitos, Mistificação, e Fatos. São Paulo : ProduQuímica. pp.
$40-62$.

Malavolta, E.; Vitti, G. C. and Oliveira, S. A. (1997), Avaliação do Estado Nutricional das Plantas Princípios e Aplicações. 2. ed. Piracicaba : Associação Brasileira para Pesquisa da Potassa e do Fosfato. pp. 234235.

Matos, A. T.; Fontes, M. P. F.; Jordão, C. D. and Costa, L. M. (1996), Mobilidade e Formas de Retenção de Metais Pesados em Latossolo Vermelho-Amarelo. R. Bras. Ci. Solo, 20, 379-386.

McBride, M. B. (1995), Toxic Metal Accumulation from Agricultural Use of Sludge: Are USEPA Regulations Protective? J. Environ. Qual., 24, 5-18.

Ministério da Agricultura. (1977), Manual de Observação de Superfície. Brasília : Instituto Nacional de Meteorologia. pp. MO-A-98.

Pavan, M. A.; Bloch, M. F.; Zempulski, H. C.; Miyazawa, M. and Zocoler, D. C. (1992), Manual de Análise Química do Solo e Controle de Qualidade. Londrina : IAPAR.

Scott, R. O.; Mitchel, R. L.; Purves, D. and Loss, C. (1971), Spectrochemical Methods for the Analysis of Soils, Plants and Agricultural Materials. Aberdeen : The Macaulay Institute for Soil Research.

Sheppard, M. J. and Thibault, D. H. (1992), Desorption and Extraction of Selected Heavy Metals from Soils. Sci. Soc. Am. J., 56, 415-423.

Silva, F. C. (Org.) (1999), Manual de Análises Químicas de Solos, Plantas e Fertilizantes. Brasília : EMBRAPA/Solos.

Silva, F. C. (1995), Uso Agronômico do Lodo de Esgoto: Efeitos em Fertilidade do Solo e Qualidade da canade-açúcar. Doctoral Thesis, Escola Superior de Agricultura "Luiz de Queiroz", Universidade de São Paulo, Piracicaba, São Paulo.

Silva, M. S. (1997), Avaliação de Parâmetros Referentes ao Chumbo (Pb) em Solos com Aplicação de Lodo de Esgoto Contaminado pelo Mesmo. Master's Thesis, Universidade Estadual de Maringá, Maringá, Paraná.

Tavares, T. M. and Carvalho, F. M. (1992), Avaliação da Exposição de Populações Humanas a Metais Pesados no Ambiente: exemplo do Recôncavo Baiano. Química Nova, 15 : (2), 147-153.

Wallace, A. and Romney, E. M. (1977), Biological implications of metals in the environment. In: Adriano, D. C. (1986), Trace Elements in the Terrestrial Environment. New York : Springer-Verlag.

Zufiaurre, R.; Olivar, A.; Chamorro, P.; Nerín, C. and Callizo, A. (1998), Speciation of Metals in Sewage Sludge for Agricultural Uses. Analyst, 123, 255-259.

Received: October 11, 2001; Revised: June 19, 2002; Accepted: March 17, 2003. 